\title{
Pengaruh Parsial Kepemimpinan, Iklim Organisiasi Dan Motivasi Terhadap Kinerja Pegawai
}

\author{
${ }^{1}$ Indra Setiawan Htb, ${ }^{2}$ Asyhariah, ${ }^{3}$ Popy Sri Istiqlalia Dewanti Nuswantari, ${ }^{4}$ Sagino \\ ${ }^{1-4}$ Program Magister Manajemen, Fakultas Ekonomi, Universitas Islam Sumatera Utara
}

\author{
Article history \\ Received: 10 Jan 2021 \\ Revised: 11 Feb 2021 \\ Accepted: 02 Mar 2021 \\ *Corresponding \\ Author: \\ Indra Setiawan Htb, \\ Program Studi \\ Magister Manajemen, \\ Fakultas Ekonomi, \\ Universitas Islam \\ Sumatera Utara \\ Email: \\ Indrasetiawanhtb@gma \\ il.com
}

Abstrak: Pemimpinan memiliki peranan yang sangat penting karena pemimpin itulah yang akan menggerakkan dan mengarahkan organisasi dalam mencapai tujuan Rumusan masalah dalam penelitian ini adalah Apakah Pengaruh Kepemimpinan, Iklim Organisasi, dan Motivasi Kerja berpengaruh terhadap Kinerja Pegawai pada Dinas Pemberdayaan Masyarakat Kelurahan, Pemberdayaan Perempuan dan Perlindungan Anak Kota Sibolga. Hasil penelitian menunjukan kepemimpinan secara parsial tidak berpengaruh positif dan juga tidak signifikan terhadap kinerja pegawai; iklim organisasi secara parsial berpengaruh positif dan signifikan terhadap kinerja pegawai; serta motivasi kerja secara parsial berpengaruh positif dan signifikan terhadap kinerja pegawai.

Kata Kunci : Kepemimpinan, Iklim Organisasi, Motivasi Kerja, Kinerja

\section{PENDAHULUAN}

Persaingan antar perusahaan di era globalisasi semakin tajam, sehingga sumber daya manusia (SDM) dituntut untuk terus menerus mampu mengembangkan diri secara proaktif. Sumber daya manusia harus menjadi manusia pembelajar, yaitu pribadi-pribadi yang mau belajar dan bekerja keras dengan penuh semangat, sehingga potensi insaninya berkembang secara maksimal. Oleh karena itu, sumber daya manusia yang diperlukan pada saat ini adalah sumber daya manusia yang mampu menguasai teknologi dengan cepat, adaptif, dan responsif terhadap perubahan-perubahan teknologi. Dalam kondisi tersebut integritas pribadi semakin penting untuk memenangkan persaingan. Manajemen sumber daya manusia memiliki peranan besar dalam memenuhi kelancaran di bidang organisasi. Organisasi perlu sumber daya manusia guna mengembangkan usahanya.

Dalam suatu organisasi, faktor kepemimpinan memegang peranan yang sangat penting karena pemimpin itulah yang akan menggerakkan dan mengarahkan organisasi dalam mencapai tujuan dan itu bukanlah merupakan hal yang mudah, sebab pemimpin harus memahami perilaku bawahan yang berbeda-beda. Bawahan dipengaruhi sedemikian rupa sehingga bisa memberikan pengabdian dan partisipasinya kepada organisasi secara efektif dan efisien. Dengan kata lain, dikatakan bahwa sukses atau tidaknya usaha pencapaian tujuan organisasi, ditentukan oleh kualitas pimpinan. Mengingat bahwa apa yang digerakkan oleh seorang pemimpin bukan benda mati, tetapi manusia yang mempunyai perasaan dan akal, serta beraneka ragam jenis dan sifatnya, maka masalah kepemimpinan tidak dapat dipandang mudah. Kemauan seorang pemimpin merupakan suatu sarana untuk mencapai tujuan. Hal ini 
berarti bawahan dalam memenuhi kebutuhan tergantung pada keterampilan dan kemauan pemimpin.

Kepemimpinan merupakan faktor penting dalam memberikan pengarahan kepada karyawan apalagi pada saat-saat sekarang ini di mana semua serba terbuka, maka kepemimpinan yang dibutuhkan adalah kepemimpinan yang bisa memberdayakan karyawannya. Kepemimpinan yang bisa menumbuhkan motivasi kerja karyawan adalah kepemimpinan yang bisa menumbuhkan rasa percaya diri para karyawan dalam menjalankan tugasnya masing-masing. Arikunto (2003:1) menyatakan bahwa "seorang pemimpin adalah seorang yang mempunyai wewenang untuk memerintah orang lain yang di dalam pekerjaannya untuk mencapai tujuan organisasi memerlukan bantuan orang lain". Sebagai seorang pemimpin ia mempunyai peranan yang aktif dan senantiasa ikut campur tangan dalam segala masalah yang berkenaan dengan kebutuhan anggota kelompoknya. Pemimpin ikut merasakan kebutuhan-kebutuhan itu dan dapat membantu menstimulir para anggotanya dalam kegiatan-kegiatan yang dilakukan salah satu tantangan yang cukup berat yang sering harus dihadapi oleh pemimpin adalah bagaimana ia dapat menggerakkan para bawahannya agar senantiasa mau dan bersedia mengerahkan kemampuan yang terbaiknya untuk kepentingan kelompok atau organisasinya.

Seringkali kita menjumpai adanya pemimpin yang menggunakan kekuasaannya secara mutlak dengan memerintahkan para bawahannya tanpa memperhatikan keadaan yang ada pada bawahannya. Hal ini jelas akan menimbulkan suatu hubungan yang tidak harmonis dalam organisasi. Menciptakan iklim organisasi yang mampu membawa anggotanya untuk meningkatkan kinerja dalam rangka pencapaian tujuan organisasi bukanlah hal yang mudah. Hal ini disebabkan karena pada dasarnya manusia memiliki karakteristik tingkah laku yang berbeda sesuai dengan kebutuhannya. Lebih lanjut dijelaskan bahwa apabila terdapat perbedaan atau kesenjangan persepsi anggota dengan pimpinan mengenai iklim yang dirasakan dan diharapkan, maka akan terciptanya ketidakpuasan kerja, motivasi kerja yang menurun, dan dapat menimbulkan penyalahgunaan hak dan kewajiban yang pada akhirnya mengakibatkan tujuan organisasi tidak dapat dipenuhi secara optimal. Persoalan ini semakin menumpuk dengan kecenderungan organisasi untuk berkembang, menyesuaikan diri dengan perkembangan lingkungan disekitarnya sehingga anggota seringkali kehilangan identitas pribadi, dan pimpinan semakin sulit untuk memuaskan kebutuhan anggota dan mencapai tujuan organisasi sekaligus. Kinerja merupakan hasil kerja dari tingkah laku. Pengertian ini mengaitkan antara hasil kerja dengan tingkah laku. Sebagai tingkah laku, kinerja merupakan aktifitas manusia yang diarahkan pada pelaksanaan tugas organisasi yang dibebankan kepadanya. Sedangkan Edy (2008:5), menjelaskan, "Kinerja adalah keluaran yang dihasilkan oleh fungsi-fungsi atau indikator-indikator suatu pekerjaan atau suatu profesi dalam waktu tertentu". Menurut Hasibuan (2003:120), banyak faktor yang dapat mempengaruhi kinerja pegawai antara lain pendidikan dan pelatihan, disiplin kerja, kompensasi, iklim organisasi, sistem jenjang karier, motivasi, kepemimpinan.

Resiko utama yang dapat mempengaruhi kinerja personil adalah keterbatasan organisasi dalam merekrut, melatih, mempertahankan, dan memotivasi personil kunci dapat mempengaruhi bisnis perseroan Buku Garuda Prospektus Final, (2010). Robbins (2006), mendefinisikan motivasi sebagai proses yang ikut menentukan intensitas, arah, dan ketekunan individu dalam usaha mencapai sasaran. Tidak hanya itu untuk mempertahankan kinerja tentu 
juga harus dibarengi oleh motivasi kerja yang tinggi, hal senada juga dikemukakan oleh Mangkunegara (2009:61) motivasi merupakan kondisi atau energi yang menggerakkan diri karyawan yang terarah atau tertuju untuk mencapai tujuan organisasi perusahaan. Sikap mental karyawan yang positif terhadap situasi kerja itulah yang memperkuat motivasi kerjanya untuk mencapai kinerja yang maksismal. Tiga unsur yang merupakan kunci dari motivasi, yaitu upaya, tujuan organisasi, dan kebutuhan. Jadi motivasi dalam hal ini sebenarnya merupakan respon dari suatu aksi. Beranjak dari permasalahan diatas penulis tertarik untuk melakukan penelitian yang diberi judul pengaruh parsial kepemimpinan, iklim organisiasi dan motivasi terhadap kinerja pegawai pada dinas pemberdayaan masyarakat kelurahan pemberdayaan perempuan dan perlindungan anak Kota Sibolga.

\section{METODE PENELITIAN}

Lokasi penelitian ini bertempat di Dinas Pemberdayaan Masyarakat Kelurahan Pemberdayaan Perempuan dan Perlindungan anak Kota sibolga Jl. MGR Albertus No 23. Kelurahan Pasar baru sibolga kota. Objek penelitian ini adalah Pengaruh Kepemimpinan, Iklim Organisasi dan Motivasi Kerja terhadap Kinerja Pegawai pada Dinas Pemberdayaan Masyarakat Kelurahan Pemberdayaan Perempuan dan Perlindungan Anak Kota Sibolga. Teknik pengumpulan data dalam penelitian ini dilakukan dengan dua cara yaitu Pengumpulan data primer dan pengumpulan data sekunder.

\section{HASIL DAN PEMBAHASAN}

Langkah pertama analisis data adalah dengan melakukan analisis terhadap karakteristik responden ini dilakukan terhadap jenis kelamin, pendidikan, dan umur dengan menggunakan tabel frekwensi, berikut hasil analisis tersebut:

\section{Identitas Responden Berdasarkan Jenis Kelamin}

Tabel 1. Identitas Responden Berdasarkan Jenis Kelamin

\begin{tabular}{cccc}
\hline No & Jenis Kelamin & Jumlah & Persentase \\
\hline 1 & Laki-laki & 17 & 40 \\
2 & Perempuan & 25 & 60 \\
& Total & 42 & 100
\end{tabular}

Sumber : Dinas PMK, PP \& PA 2020

Berdasarkan Tabel diatas diketahui bahwa responden yang berjenis kelamin lakilaki berjumlah 17 orang (40\%) dan perempuan 25 orang ( 60\%). Fenomena ini disebabkan karena karakteristik dari pelayanan Dinas PMK, PP \& PA, lebih cinderung berhubungan dengan masyarakat penyuluhan untuk perempuan dan perlindungan anak yang peran tersebut mampu di dominasi oleh perempuan.

Tabel 2. Identitas Responden Berdasarkan Tingkat Pendidikan

\begin{tabular}{cccc}
\hline No & Tingkat Pendidikan & Jumlah & Persentase \\
\hline 1 & SMA & 28 & 67 \\
2 & D3 & 1 & 2 \\
3 & S1 & 9 & 21,5 \\
4 & S2 & 4 & 9,5 \\
& Total & 42 & 100
\end{tabular}


Sumber : Dinas PMK, PP \& PA 2020

\section{a. Skor Angket Variabel Kepemimpinan $\left(\mathrm{X}_{1}\right)$}

Tabel 3. Skor Angket Variabel Kepemimpinan

\begin{tabular}{|c|c|c|c|c|c|c|c|c|c|c|c|c|}
\hline \multirow{3}{*}{ NO } & \multicolumn{12}{|c|}{ ALTERNATIVE JAWABAN } \\
\hline & \multicolumn{2}{|r|}{$\mathbf{a}$} & \multicolumn{2}{|c|}{$\mathbf{B}$} & \multicolumn{2}{|c|}{ c } & \multicolumn{2}{|r|}{ d } & \multicolumn{2}{|r|}{ 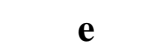 } & \multicolumn{2}{|c|}{ jumlah } \\
\hline & $\mathbf{f}$ & $\%$ & f & $\%$ & f & $\%$ & $\mathbf{f}$ & $\%$ & $\mathbf{f}$ & $\%$ & f & $\%$ \\
\hline 1 & 23 & 54,76 & 11 & 26,2 & 8 & 19 & 0 & 0 & 0 & 0 & 42 & 100 \\
\hline 2 & 29 & 69,05 & 6 & 14,3 & 5 & 11,9 & 1 & 2,38 & 1 & 2,38 & 42 & 100 \\
\hline 3 & 21 & & 5 & 11,9 & 10 & 23,8 & 5 & 11,9 & 1 & 2,38 & 42 & 100 \\
\hline 4 & 25 & 59,52 & 12 & 28,6 & 3 & 7,14 & 2 & 4,76 & 0 & م & 42 & 100 \\
\hline 5 & 31 & & 8 & 19 & 3 & 7,14 & 0 & 0 & o & & 42 & 100 \\
\hline 6 & 20 & 47,62 & 12 & 28,6 & 7 & 16,7 & 3 & 7,14 & 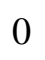 & 0 & 42 & 100 \\
\hline 7 & 26 & 61,9 & 7 & 16,7 & 6 & 14,3 & 3 & 7,14 & o & 0 & 42 & 100 \\
\hline 8 & 19 & 45,24 & 7 & 16,7 & 11 & 26,2 & 5 & 11,9 & 0 & $\sigma$ & 42 & 100 \\
\hline 9 & 21 & 50 & 17 & 40,5 & 3 & 7,14 & 1 & 2,38 & 0 & 0 & 42 & 100 \\
\hline 10 & 27 & 64,29 & 10 & 23,8 & 4 & 9,52 & 1 & 2,38 & 0 & 0 & 42 & 100 \\
\hline
\end{tabular}

Sumber : Data diolah SPSS-2020

Dari tabel di atas dijelaskan bahwa :

1. Jawaban responden untuk pertanyaan No. 1 : Saya tau apa yang diharapkan pimpinan

Responden yang menjawab sangat setuju 23 orang $(54,76 \%)$ setuju 11 orang ( $26,2 \%)$ kurang setuju 8 orang $(19 \%)$ tidak setuju 0 orang $(0 \%)$ dan sangat tidak setuju 0 orang $(0 \%)$.

2. Jawaban responden untuk pertanyaan No. 2 : Pimpinan selalu memberi pengarahan khusus.

Responden yang menjawab sangat setuju 29 orang $(69,05 \%)$ setuju 6 orang $(14,3 \%)$ kurang setuju 5 orang $(11,9 \%)$ tidak setuju 1 orang $(2,38 \%)$ dan sangat tidak setuju 1 orang $(2,38 \%)$.

3. Jawaban responden untuk pertanyaan No. 3 : Pimpinan mampu menciptakan suana kerja yang kodusif.

Responden yang menjawab sangat setuju 21 orang $(50 \%)$ setuju 5 orang $(11,9 \%)$ kurang setuju 10 orang $(23,8 \%)$ tidak setuju 5 orang $(11,9 \%)$ dan sangat tidak setuju 1 orang $(2,38 \%)$.

4. Jawaban responden untuk pertanyaan No. 4 : Suasana kondusif selalu dipelihara dengan baik.

Responden yang menjawab sangat setuju 25 orang $(59,52 \%)$ setuju 12 orang $(28,6 \%)$ kurang setuju 3 orang $(7,14 \%)$ tidak setuju 2 orang $(4,76 \%)$ dan sangat tidak setuju 0 orang $(0 \%)$.

5. Jawaban responden untuk pertanyaan No. 5 : Pimpinan selalu memperhatikan kesejahteraan pegawainya.

Responden yang menjawab sangat setuju 31 orang $(73,81 \%)$ setuju 8 orang (19\%) kurang setuju 3 orang $(7,14 \%)$ tidak setuju 0 orang $(0 \%)$ dan sangat tidak setuju 0 orang $(0 \%)$. 
6. Jawaban responden untuk pertanyaan No. 6 : Pimpinan selalu memberikan kebebasan dalam berpendapat.

Responden yang menjawab sangat setuju 20 orang $(47,62 \%)$ setuju 12 orang $(28,6 \%)$ kurang setuju 7 orang $(16,7 \%)$ tidak setuju 3 orang $(7,14 \%)$ dan sangat tidak setuju 0 orang $(0 \%)$.

7. Jawaban responden untuk pertanyaan No. 7 : Kebebasan dalam berpendapat berlaku pada setiap pegawai dengan bermacam tingkatan dan kedudukan.

Responden yang menjawab sangat setuju 26 orang $(61,9 \%)$ setuju 7 orang $(16,7 \%)$ kurang setuju 6 orang $(14,3 \%)$ tidak setuju 3 orang $(7,14 \%)$ dan sangat tidak setuju 0 orang $(0 \%)$.

8. Jawaban responden untuk pertanyaan No. 8 : Pimpinan selalu mampu dalam menetapkan tujuan

Responden yang menjawab sangat setuju 19 orang $(14,24 \%)$ setuju 7 orang $(16,7 \%)$ kurang setuju 11 orang $(26,2 \%)$ tidak setuju 5 orang $(11,6 \%)$ dan sangat tidak setuju 0 orang $(0 \%)$.

9. Jawaban responden untuk pertanyaan No. 9 : Saya dituntut berkontribusi dalam menetapkan tujuan organisasi.

Responden yang menjawab sangat setuju 20 orang (50\%) setuju 17 orang $(40,5 \%)$ kurang setuju 3 orang $(7,14 \%)$ tidak setuju 1 orang $(2,38 \%)$ dan sangat tidak setuju 0 orang $(0 \%)$.

10. Jawaban responden untuk pertanyaan No. 10 : Pimpinan percaya bahwa saya mampu mencapai standart kerja yang tinggi.

Responden yang menjawab sangat setuju 27 orang (64,29\%) setuju 10 orang $(23,8 \%)$ kurang setuju 4 orang $(9,52 \%)$ tidak setuju 1 orang $(2,38 \%)$ dan sangat tidak setuju 0 orang $(0 \%)$.

\section{b. Skor Angket Variabel Iklim Organisasi $\left(\mathbf{X}_{2}\right)$}

Tabel 4. Skor Angket Variabel Iklim Organisasi

\begin{tabular}{|c|c|c|c|c|c|c|c|c|c|c|c|c|}
\hline \multirow{3}{*}{ NO } & \multicolumn{12}{|c|}{ ALTERNATIVE JAWABAN } \\
\hline & \multicolumn{2}{|r|}{$\mathbf{a}$} & \multicolumn{2}{|r|}{ b } & \multicolumn{2}{|c|}{$\mathbf{c}$} & \multicolumn{2}{|c|}{ d } & \multicolumn{2}{|r|}{ 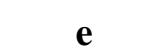 } & \multicolumn{2}{|c|}{ Jumlah } \\
\hline & $\mathbf{f}$ & $\%$ & f & $\%$ & $\mathbf{f}$ & $\%$ & $\mathbf{f}$ & $\%$ & $\mathbf{f}$ & $\%$ & f & $\%$ \\
\hline 1 & 16 & 38,1 & 11 & 26,2 & 10 & 3,8 & 5 & 1,9 & O & 0 & 42 & 100 \\
\hline 2 & 16 & 3,1 & 12 & 28,6 & 9 & 21,4 & $J$ & 11,9 & $\sigma$ & 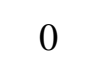 & 42 & 100 \\
\hline 3 & 19 & & 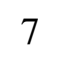 & 16,7 & 6 & & 0 & & 2 & & 42 & 100 \\
\hline 4 & 18 & 42,8 & 8 & 19 & 7 & 16,7 & 6 & 14,3 & 3 & 7,14 & 42 & 100 \\
\hline 5 & 15 & & 7 & 16,7 & 11 & 26,2 & 6 & 14,3 & 3 & 7,14 & 42 & 100 \\
\hline 6 & 22 & 52,38 & 5 & 11,9 & 8 & 19 & 6 & 14,3 & 1 & 2,38 & 42 & 100 \\
\hline 7 & 16 & 201 & 13 & 31 & 8 & 19 & 5 & 11,9 & 0 & 0 & 42 & 100 \\
\hline 8 & 20 & 47,6 & 13 & 31 & 4 & 9,52 & 5 & 11,9 & 0 & 0 & 42 & 100 \\
\hline 9 & 14 & 33,33 & 8 & 19 & 9 & 21,4 & 7 & 16,7 & 4 & 9,52 & 42 & 100 \\
\hline 10 & 17 & 40,48 & 13 & 31 & 7 & 16,7 & 5 & 11,9 & 0 & 0 & 42 & 100 \\
\hline
\end{tabular}

Sumber : Data diolah SPSS-2020

Dari tabel 4 di atas dijelaskan bahwa : 
1. Jawaban responden untuk pertanyaan No. 1 : Sistem kepemimpinan di instansi tempat saya bekerja sangat baik.

Responden yang menjawab sangat setuju 16 orang $(38,1 \%)$ setuju 11 orang ( $26,2 \%)$ kurang setuju 10 orang $(23,8 \%)$ tidak setuju 5 orang $(11,9 \%)$ dan sangat tidak setuju 0 orang $(0 \%)$.

2. Jawaban responden untuk pertanyaan No. 2 : Pimpinan saya selalu memotivasi bawahannya.

Responden yang menjawab sangat setuju 16 orang $(38,1 \%)$ setuju 12 orang ( $28,6 \%)$ kurang setuju 9 orang $(21,4 \%)$ tidak setuju 5 orang $(11,9 \%)$ dan sangat tidak setuju 0 orang $(0 \%)$.

3. Jawaban responden untuk pertanyaan No. 3 : Saya memiliki motivasi kerja yang baik.

Responden yang menjawab sangat setuju 19 orang $(45,24 \%)$ setuju 7 orang $(16,7 \%)$ kurang setuju 6 orang $(14,3 \%)$ tidak setuju 8 orang $(19 \%)$ dan sangat tidak setuju 2 orang $(4,76 \%)$.

4. Jawaban responden untuk pertanyaan No. 4 : Komunikasi yang baik mampu meningkatkan kinerja pegawai.

Responden yang menjawab sangat setuju 18 orang (42,86\%) setuju 8 orang ( $19 \%)$ kurang setuju 7 orang $(16,7 \%)$ tidak setuju 6 orang $(14,3 \%)$ dan sangat tidak setuju 3 orang $(7,14 \%)$.

5. Jawaban responden untuk pertanyaan No. 5 : Pimpinan selalu berkomunikasi dengan baik kepada bawahannya.

Responden yang menjawab sangat setuju 15 orang $(35,71 \%)$ setuju 7 orang ( $16,7 \%)$ kurang setuju 11 orang $(26,2 \%)$ tidak setuju 6 orang $(14,3 \%)$ dan sangat tidak setuju 3 orang $(7,14 \%)$.

6. Jawaban responden untuk pertanyaan No. 6 : Instansi tempat saya bekerja instansi sesama pegawai haruslah efektif dan efesien.

Responden yang menjawab sangat setuju 22 orang $(52,38 \%)$ setuju 5 orang ( $11,9 \%)$ kurang setuju 8 orang $(19 \%)$ tidak setuju 6 orang $(14,3 \%)$ dan sangat tidak setuju 1 orang $(2,38 \%)$.

7. Jawaban responden untuk pertanyaan No. 7 : Pimpinan selalu bermusyawarah dalam pengambilan keputusan.

Responden yang menjawab sangat setuju 16 orang $(38,1 \%)$ setuju 13 orang ( $31 \%)$ kurang setuju 8 orang (19\%) tidak setuju 5 orang $(11,9 \%)$ dan sangat tidak setuju 0 orang $(0 \%)$.

8. Jawaban responden untuk pertanyaan No. 8 : Saya selalu berpartisipasi dalam penyusunan tujuan organisasi.

Responden yang menjawab sangat setuju 20 orang (47,62\%) setuju 13 orang ( $31 \%)$ kurang setuju 4 orang $(9,52 \%)$ tidak setuju 5 orang $(11,9 \%)$ dan sangat tidak setuju 0 orang $(0 \%)$.

9. Jawaban responden untuk pertanyaan No. 9 : Saya dituntut untuk melakukan pengendalian kerja apabila di butuhkan. 
Responden yang menjawab sangat setuju 14 orang (33,33\%) setuju 8 orang (19\%) kurang setuju 9 orang $(21,4 \%)$ tidak setuju 7 orang $(16,7 \%)$ dan sangat tidak setuju 4 orang $(9,52 \%)$.

10. Jawaban responden untuk pertanyaan No. 10: Para pegawai mampu mengendalikan segala problematika kerja yang terjadi.

Responden yang menjawab sangat setuju 17 orang (40,48\%) setuju 13 orang ( $31 \%)$ kurang setuju 7 orang $(16,7 \%)$ tidak setuju 5 orang $(11,9 \%)$ dan sangat tidak setuju 0 orang $(0 \%)$.

\section{c. Skor Angket Variabel Motivasi $\left(\mathbf{X}_{3}\right)$}

Tabel 5. Skor Angket Variabel Motivasi

\begin{tabular}{|c|c|c|c|c|c|c|c|c|c|c|c|c|}
\hline \multirow{3}{*}{ NO } & \multicolumn{12}{|c|}{ ALTERNATIVE JAWABAN } \\
\hline & \multicolumn{2}{|r|}{$\mathbf{a}$} & \multicolumn{2}{|c|}{$\mathbf{B}$} & \multicolumn{2}{|c|}{$\mathbf{C}$} & \multicolumn{2}{|r|}{ d } & \multicolumn{2}{|r|}{$\mathbf{e}$} & \multicolumn{2}{|c|}{ jumlah } \\
\hline & $\mathbf{f}$ & $\%$ & f & $\%$ & $\mathbf{f}$ & $\%$ & $\mathbf{f}$ & $\%$ & f & $\%$ & f & $\%$ \\
\hline 1 & 19 & $\overline{5,24}$ & 7 & 16,7 & 5 & 11,9 & 8 & 19 & 20 & 7,14 & 42 & 100 \\
\hline 2 & 20 & 47.6 & 11 & 26,2 & 6 & 14,3 & 5 & 11,9 & 0 & 0 & 42 & 100 \\
\hline 3 & 23 & & 11 & 26,2 & 5 & 11 & 3 & & & 0 & 42 & 100 \\
\hline 4 & 20 & 47,6 & 11 & 26,2 & 6 & 14 , & 5 & 11,9 & 0 & 0 & 42 & 100 \\
\hline 5 & 23 & & 12 & 28,6 & 3 & & 4 & 9,52 & $\sigma$ & 0 & 42 & 100 \\
\hline 6 & 24 & 57 & 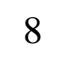 & 19 & 5 & 11 & 4 & 9,52 & 1 & 2, & 42 & 100 \\
\hline 7 & 22 & & 11 & 26,2 & 5 & 11 & 3 & 7,14 & 1 & 2,38 & 42 & 100 \\
\hline 8 & 23 & 54,76 & 11 & 26,2 & 5 & 11 & 3 & 7,14 & 0 & 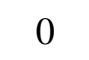 & 42 & 100 \\
\hline 9 & 21 & 50 & 13 & 31 & 4 & 9,52 & 4 & 9,52 & 0 & 0 & 42 & 100 \\
\hline 10 & 22 & 52,38 & 11 & 26,2 & 5 & 11,9 & 4 & 9,52 & 0 & 0 & 42 & 100 \\
\hline
\end{tabular}

Sumber : Data diolah SPSS-2020

Dari tabel 5 di atas dijelaskan bahwa :

1. Jawaban responden untuk pertanyaan No. 1 : Saya selalu memiliki target kerja untuk selalu berprestasi

Responden yang menjawab sangat setuju 19 orang $(45,24 \%)$ setuju 7 orang ( $16,7 \%)$ kurang setuju 5 orang (11,9\%) tidak setuju 8 orang (19\%) dan sangat tidak setuju 0 orang $(0 \%)$.

2. Jawaban responden untuk pertanyaan No. 2 : Saya dituntut oleh pimpinan untuk memperhatikan kualitas kerja

Responden yang menjawab sangat setuju 20 orang $(47,62 \%)$ setuju 11 orang ( $26,2 \%)$ kurang setuju 6 orang $(14,3 \%)$ tidak setuju 5 orang $(19,9 \%)$ dan sangat tidak setuju 0 orang $(0 \%)$

3. Jawaban responden untuk pertanyaan No. 3 : Saya dituntut untu bertanggung jawab dalam pekerjaan

Responden yang menjawab sangat setuju 23 orang (54,76\%) setuju 11 orang ( $26,2 \%)$ kurang setuju 6 orang $(14,3 \%)$ tidak setuju 5 orang $(11,9 \%)$ dan sangat tidak setuju 0 orang $(0 \%)$.

4. Jawaban responden untuk pertanyaan No. 4 : Pimpinan menuntut saya untuk memperkecil resiko kerja 
Responden yang menjawab sangat setuju 20 orang (47,62\%) setuju 11orang ( $26,2 \%)$ kurang setuju 6 orang $(14,3 \%)$ tidak setuju 5 orang $(11,9 \%)$ dan sangat tidak setuju 0 orang $(0 \%)$.

5. Jawaban responden untuk pertanyaan No. 5 : Saya selalu aktif berkomunikasi untuk memperluas pergaulan

Responden yang menjawab sangat setuju 23 orang (45,76\%) setuju 12 orang ( $9,52 \%)$ kurang setuju 3 orang $(7,14 \%)$ tidak setuju 4 orang $(11,9 \%)$ dan sangat tidak setuju 0 orang $(0 \%)$.

6. Jawaban responden untuk pertanyaan No. 6 : Instansi tempat saya bekerja selalu menunjukan nilai persahabatan yang kuat

Responden yang menjawab sangat setuju 24 orang $(57,14 \%)$ setuju 8 orang ( $19 \%)$ kurang setuju 5 orang $(11,9 \%)$ tidak setuju 4 orang $(9,52 \%)$ dan sangat tidak setuju 1 orang $(2,38 \%)$.

7. Jawaban responden untuk pertanyaan No. 7 : Pimpinan saya menunjukan sikap pemimpin yang baik

Responden yang menjawab sangat setuju 22 orang $(52,38 \%)$ setuju 11 orang ( $26,2 \%)$ kurang setuju 5 orang $(11,9 \%)$ tidak setuju 3 orang $(7,14 \%)$ dan sangat tidak setuju 1 orang $(2,38 \%)$.

8. Jawaban responden untuk pertanyaan No. 8 : Saya sering dijadikan duta dari banyaknya aktivitas instansi

Responden yang menjawab sangat setuju 23 orang $(54,76 \%)$ setuju 11 orang ( $26,2 \%)$ kurang setuju 5 orang $(11,9 \%)$ tidak setuju 3 orang $(7,14 \%)$ dan sangat tidak setuju 0 orang $(0 \%)$.

9. Jawaban responden untuk pertanyaan No. 9 : Setiap pegawai memiliki keteladanan dalam bekerja

Responden yang menjawab sangat setuju 21 orang (50\%) setuju 13 orang (31\%) kurang setuju 4 orang $(9,52 \%)$ tidak setuju 4 orang $(9,52 \%)$ dan sangat tidak setuju 0 orang $(0 \%)$.

10. Jawaban responden untuk pertanyaan No. 10 : Pimpinan memberi motivasi untuk terus mempertahankan keteladanan dalam bekerja

Responden yang menjawab sangat setuju 22 orang $(52,38 \%)$ setuju 11 orang $(26,2 \%)$ kurang setuju 5 orang $(11,9 \%)$ tidak setuju 4 orang $(9,52 \%)$ dan sangat tidak setuju 0 orang $(0 \%)$.

\section{d. Skor Angket Variabel Kinerja (Y)}

Tabel 6. Skor Angket Variabel Kinerja

\begin{tabular}{|c|c|c|c|c|c|c|c|c|c|c|c|c|}
\hline \multirow{3}{*}{ NO } & \multicolumn{12}{|c|}{ ALTERNATIVE JAWABAN } \\
\hline & \multicolumn{2}{|r|}{$\mathbf{a}$} & \multicolumn{2}{|c|}{ B } & \multicolumn{2}{|c|}{$\mathbf{C}$} & \multicolumn{2}{|c|}{ d } & \multicolumn{2}{|r|}{ e } & \multicolumn{2}{|c|}{ Jumlah } \\
\hline & $\mathbf{f}$ & $\%$ & $\mathbf{f}$ & $\%$ & f & $\%$ & f & $\%$ & f & $\%$ & f & $\%$ \\
\hline 1 & 19 & 45,24 & 2 & 4,76 & 8 & 19 & 7 & 16,7 & 6 & 14,3 & 42 & 100 \\
\hline 2 & 24 & 57,14 & 5 & 11,9 & 8 & 19 & 5 & 11,9 & 0 & 0 & 42 & 100 \\
\hline 3 & 20 & 47,62 & 12 & 28,6 & 5 & 11,9 & 5 & 11,9 & 0 & 0 & 42 & 100 \\
\hline 4 & 16 & 38,1 & 8 & 19 & 13 & 31 & 5 & 11,9 & 0 & 0 & 42 & 100 \\
\hline 5 & 27 & 64,29 & 7 & 16,7 & 7 & 16,7 & 1 & 2,38 & 0 & 0 & 42 & 100 \\
\hline
\end{tabular}




$\begin{array}{ccccccccccccc}6 & 21 & 50 & 6 & 14,3 & 8 & 19 & 5 & 11,9 & 2 & 4,76 & 42 & 100 \\ 7 & 15 & 35,71 & 12 & 28,6 & 10 & 23,8 & 5 & 11,9 & 0 & 0 & 42 & 100 \\ 8 & 20 & 47,62 & 12 & 28,6 & 5 & 11,9 & 5 & 11,9 & 0 & 0 & 42 & 100 \\ 9 & 26 & 61,9 & 11 & 26,2 & 4 & 9,52 & 1 & 2,38 & 0 & 0 & 42 & 100 \\ 10 & 20 & 47,62 & 6 & 14,3 & 11 & 26,2 & 5 & 11,9 & 0 & 0 & 42 & 100\end{array}$

Sumber : Data diolah SPSS-2020

Dari tabel 6 diatas dijelaskan bahwa :

1. Jawaban responden untuk pertanyaan No. 1 : Saya mampu menghasilkan kinerja yang berkualitas.

Responden yang menjawab sangat setuju 19 orang $(45,24 \%)$ setuju 2 orang ( $4,76 \%)$ kurang setuju 8 orang (19\%) tidak setuju 7 orang $(16,7 \%)$ dan sangat tidak setuju 6 orang $(14,3 \%)$.

2. Jawaban responden untuk pertanyaan No. 2 : Pimpinan selalu mengapresiasi kualitas kerja bawahannya.

Responden yang menjawab sangat setuju 24 orang $(57,14 \%)$ setuju 5 orang ( $11,9 \%)$ kurang setuju 8 orang (19\%) tidak setuju 5 orang $(11,9 \%)$ dan sangat tidak setuju 0 orang $(0 \%)$.

3. Jawaban responden untuk pertanyaan No. 3 : Kualitas selalu menjadi prioritas pimpinan.

Responden yang menjawab sangat setuju 20 orang $(47,62 \%)$ setuju 12 orang ( $28,6 \%)$ kurang setuju 5 orang $(11,9 \%)$ tidak setuju 5 orang $(11,9 \%)$ dan sangat tidak setuju 0 orang $(0 \%)$.

4. Jawaban responden untuk pertanyaan No. 4 : Instansi tempat saya bekerja dipenuhi oleh SDM yang mampu mencapai kualitas kerja.

Responden yang menjawab sangat setuju 16 orang $(38,1 \%)$ setuju 8 orang ( $19 \%)$ kurang setuju 13 orang $(31 \%)$ tidak setuju 5 orang $(11,9 \%)$ dan sangat tidak setuju 0 orang $(0 \%)$.

5. Jawaban responden untuk pertanyaan No. 5 : Saya dituntut untuk bekerja dengan tepat.

Responden yang menjawab sangat setuju 27 orang $(64,29 \%)$ setuju 7 orang ( $16,7 \%)$ kurang setuju 7 orang $(16,7 \%)$ tidak setuju 1 orang $(2,38 \%)$ dan sangat tidak setuju 0 orang $(0 \%)$.

6. Jawaban responden untuk pertanyaan No. 6 : Saya memprioritas ketepatan dalam bekerja.

Responden yang menjawab sangat setuju 21 orang (50\%) setuju 6 orang ( $14,3 \%)$ kurang setuju 8 orang (19\%) tidak setuju 5 orang $(11,9 \%)$ dan sangat tidak setuju 2 orang $(4,76 \%)$.

7. Jawaban responden untuk pertanyaan No. 7 : Saya dituntut untuk mengutamakan efektivitas kerja.

Responden yang menjawab sangat setuju 15 orang $(35,71 \%)$ setuju 12 orang ( $28,6 \%)$ kurang setuju 10 orang $(23,8 \%)$ tidak setuju 5 orang $(11,9 \%)$ dan sangat tidak setuju 2 orang $(4,76 \%)$.

8. Jawaban responden untuk pertanyaan No. 8 : Efektivitas kerja sangat di prioritaskan oleh para pegawai. 
Responden yang menjawab sangat setuju 20 orang $(47,62 \%)$ setuju 12 orang ( $28,6 \%)$ kurang setuju 5 orang $(11,9 \%)$ tidak setuju 5 orang $(11,9 \%)$ dan sangat tidak setuju 0 orang $(0 \%)$.

9. Jawaban responden untuk pertanyaan No. 9 : Setiap pegawai memiliki kemandirian dalam bekerja.

Responden yang menjawab sangat setuju 26 orang (61,9\%) setuju 11 orang $(26,2 \%)$ kurang setuju 4 orang $(9,52 \%)$ tidak setuju 1 orang $(2,38 \%)$ dan sangat tidak setuju 0 orang $(0 \%)$.

10. Jawaban responden untuk pertanyaan No. 10 : Pimpinan selalu mengajarkan kemandirian kepada bawahannya.

Responden yang menjawab sangat setuju 20 orang $(47,62 \%)$ setuju 6 orang $(14,3 \%)$ kurang setuju 11 orang $(26,2 \%)$ tidak setuju 5 orang $(11,9 \%)$ dan sangat tidak setuju 0 orang $(0 \%)$.

\section{Uji Kualitas Data}

\section{Uji Validitas Data}

Uji validitas dilakukan untuk mengetahui apakah alat ukur yang telah disusun dapat digunakan untuk mengukur apa yang hendak diukur secara tepat. Validitas suatu instrumen menggambarkan tingkat kemampuan alat ukur yang digunakan untuk mengungkapkan sesuatu yang menjadi sasaran pokok pengukuran. Bila iinstrumen tersebut mampu untuk mengukur variabel yang diukur maka disebut sebagai valid. Dan sebaiknya apabila tidak mampu untuk mengukur variabel yang diukur maka akan disebut tidak valid.

Pengujian validitas instrumen menggunakan Analyst Correlate Bivariate untuk mencari Correlation Coefisient dari Product moment pearson dengan derajat kebebasan $(\mathrm{dk}=\mathrm{n}-2)$ sehingga didapat $\mathrm{r}_{\text {tabel. }}$. Untuk butir pertanyaan dengan nilai koefisien kolerasi ( $r_{\text {hitung }}>r_{\text {tabel }}$ ) maka butir pertanyaan tersebut dinyatakan valid. Karena jumlah responden yang digunakan untuk uji validitas sebanyak 42 orang maka nilai $r_{\text {tabel }}$ ditentukan dari

$$
\mathrm{dk}=\mathrm{n}-\mathbf{2}=\mathbf{4 2}-\mathbf{2}=40
$$

Tabel 7. Hasil Uji Validitas Variabel $\left(\mathrm{X}_{1}\right)$

\begin{tabular}{cccc}
\hline Variabel & $\mathbf{r}_{\text {hitung }}$ & $\mathbf{r}_{\text {tabel }}$ & Keterangan \\
\hline 1 & 0,741 & 0,304 & Valid \\
2 & 0,735 & 0,304 & Valid \\
3 & 0,672 & 0,304 & Valid \\
4 & 0,423 & 0,304 & Valid \\
5 & 0,695 & 0,304 & Valid \\
6 & 0,437 & 0,304 & Valid \\
7 & 0,751 & 0,304 & Valid \\
8 & 0,490 & 0,304 & Valid \\
9 & 0,636 & 0,304 & Valid \\
10 & 0,739 & 0,304 & Valid
\end{tabular}

Sumber : Data diolah-2020 
Tabel 8. Hasil Uji Validitas Variabel $\left(\mathrm{X}_{2}\right)$

\begin{tabular}{cccc}
\hline Variabel & $\mathbf{r}_{\text {hitung }}$ & $\mathbf{r}_{\text {tabel }}$ & Keterangan \\
\hline 1 & 0,521 & 0,304 & Valid \\
2 & 0,567 & 0,304 & Valid \\
3 & 0,419 & 0,304 & Valid \\
4 & 0,647 & 0,304 & Valid \\
5 & 0,428 & 0,304 & Valid \\
6 & 0,674 & 0,304 & Valid \\
7 & 0,662 & 0,304 & Valid \\
8 & 0,435 & 0,304 & Valid \\
9 & 0,519 & 0,304 & Valid \\
10 & 0,533 & 0,304 & Valid
\end{tabular}

Sumber : Data diolah-2020

Tabel 9. Hasil Uji Validitas Variabel $\left(\mathrm{X}_{3}\right)$

\begin{tabular}{cccc} 
Variabel & $\mathbf{r}_{\text {hitung }}$ & $\mathbf{r}_{\text {tabel }}$ & Keterangan \\
\hline 1 & 0,521 & 0,304 & Valid \\
2 & 0,716 & 0,304 & Valid \\
3 & 0,405 & 0,304 & Valid \\
4 & 0,754 & 0,304 & Valid \\
5 & 0,870 & 0,304 & Valid \\
6 & 0,680 & 0,304 & Valid \\
7 & 0,391 & 0,304 & Valid \\
8 & 0,405 & 0,304 & Valid \\
9 & 0,823 & 0,304 & Valid \\
10 & 0,791 & 0,304 & Valid
\end{tabular}

Sumber : Data diolah-2020

Tabel 10. Hasil Uji Validitas Variabel (Y)

\begin{tabular}{cccc}
\hline Variabel & $\mathbf{r}_{\text {hitung }}$ & $\mathbf{r}_{\text {tabel }}$ & Keterangan \\
\hline 1 & 0,521 & 0,304 & Valid \\
2 & 0,716 & 0,304 & Valid \\
3 & 0,405 & 0,304 & Valid \\
4 & 0,754 & 0,304 & Valid \\
5 & 0,870 & 0,304 & Valid \\
6 & 0,680 & 0,304 & Valid \\
7 & 0,391 & 0,304 & Valid \\
8 & 0,405 & 0,304 & Valid \\
9 & 0,823 & 0,304 & Valid \\
10 & 0,791 & 0,304 & Valid
\end{tabular}


Sumber : Data diolah-2020

Berdasarkan tabel 8 hingga 10 seluruh pernyataan dalam setiap variabel memiliki nilai corrected item correlation ( $r_{\text {hitung }}$ ) lebih besar dari $r_{\text {tabel. }}$.

\section{Uji Reliabilitas Data}

Reliabilitas instrument menggambarkan pada kemantapan alat ukur yang digunakan. Suatu alat ukur dikatakan memiliki reliabilitas yang tinggi atau dapat sipercaya, apabila alat ukur tersebut stabil sehingga dapat dipercaya, apabila alat ukur tersebut stabil sehingga dapat diandalkan (dependability) dan dapat digunakan untuk meramalkan ( predictability).

Pada penelitian ini, uji reliabilitas menggunakan metode Cronbach Alpha. Reliabilitas diukur dengan menguji tingkat konsistensi hasil pengukuran jika dilakukan pengukuran ulang. Andal atau tidaknya suatu data dapat dilihat dari koefisien alpha yang dihasilkan, data yang mendekati angak 1 ( satu) dapat dikatakan memiliki keandalan tinggi. Nilai Koefisien Cronbach Alpha yang mendekati 1 (satu) menunjukan bahwa hasil yang diperoleh semakin konsisten sehingga dikatakan mempunyai reliabilitas yang tinggi. Suata data dikatakan akurat jika nilai Koefisien Cronbach Alpha minimu adalah 0,60. Uji reliabilitas pada penelitian ini menggunakan program SPSS versi 19.

\section{Tabel 11. Hasil Uji Realibilitas}

\begin{tabular}{cccc}
\hline Variable & $\begin{array}{c}\text { Cronbach's } \\
\text { Alpha }\end{array}$ & N of Item & Keterangan \\
\hline $\mathrm{X}_{1}$ & 0,818 & 10 & Reliabel \\
$\mathrm{X}_{2}$ & 0,886 & 10 & Reliabel \\
$\mathrm{X}_{3}$ & 0,887 & 10 & Reliabel \\
$\mathrm{Y}$ & 0,842 & 10 & Reliabel
\end{tabular}

Sumber: Data diolah-2020

Berdasarkan tabel 5.12. diatas terlihat bahwa milai Cronbach Alpha seluruh variabel berkisar antara 0 sampai 1 dan lebih cendrung mendekati angka 1, dengan demikian keseluruhan item dalam instrumen pengukuran dapat dikategorikan sangat reliabel.

\section{Pengujian Hipotesis}

Dalam evaluasi data ini saya akan melakukan pengujian hipotesis, baik secara partial ataupun secara simultan, selanjutnya untuk mempermudah dalam evaluasi data ini maka saya mencari nilai-nilai yang dibutuhkan dengan menggunakan perangkat lunak komputer yaitu Program SPSS V 19.00 for windows dengan hasil data sebagai berikut :

Tabel 12 . Hasil Uji Statistik Koefisien Regresi

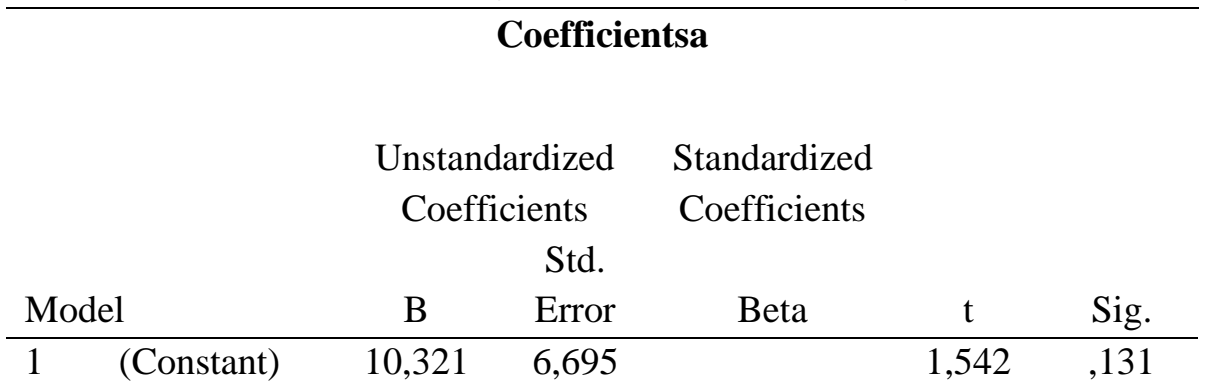




$\begin{array}{cccccc}\text { Kepemimpinan } & , 018 & , 131 & , 015 & , 139 & , 890 \\ \begin{array}{ccccc}\text { Iklim } \\ \text { Organisasi }\end{array} & , 373 & , 107 & , 452 & 3,483 & , 001 \\ \begin{array}{l}\text { Motivasi } \\ \text { : 366 }\end{array} & , 117 & , 402 & 3,122 & , 003 \\ \text { Butput SPSS Data diolah-2020 } & & & \end{array}$

Berdasarkan tabel-5.13. diatas dapat dibuat persamaan regresi sebagai berikut : $Y=$ $10,321+0,018+0,373+0,366+€$.

Berdasarkan persamaan diatas dijelaskan bahwa koefisien $\mathrm{X}_{1}$ (Kepemimpinan) mempunyai nilai positif yaitu 0,018 , hal ini menunjukan bahwa variabel Kepemimpinan mempunyai pengaruh positif terhadap Kinerja pegawai. Jadi bila Kepemimpinan baik maka akan berdampak positif terhadap Kinerja pegawai pada Dinas PMK, PP \& PA Kota Sibolga. Berdasarkan persamaan diatas dijelaskan bahwa koefisien $\mathrm{X}_{2}$ (Iklim Organisasi) mempunyai nilai positif yaitu 0,373 , hal ini menunjukan bahwa variabel Iklim organisasi mempunyai pengaruh positif terhadap Kinerja. Jadi Iklim organisasi yang baik akan berdampak positif terhadap Kinerja pegawai pada Dinas PMK, PP \& PA Kota Sibolga. Berdasarkan persamaan diatas dijelaskan bahwa koefisien $\mathrm{X}_{3}$ (Motivasi) mempunyai nilai positif yaitu 0,366, hal ini menunjukan bahwa variabel Motivasi mempunyai pengaruh positif terhadap Kinerja. Jadi Motivasi yang tinggi akan berdampak positif terhadap produktivitas pegawai pada Dinas PMK, PP \& PA Kota Sibolga.

\section{KESIMPULAN}

Variabel Kepemimpinan tidak berpengaruh dan tidak signifikan terhadap Kinerja Pegawai pada Dinas PMK,PP,PA Kota Sibolga dengan nilai $t_{\text {hitung }}<t_{\text {tabel }}(0,139<2,018)$. Iklim Organisasi secara parsial berpengaruh dan signifikan terhadap Kinerja Pegawai pada Dinas PMK,PP,PA Kota Sibolga dengan nilai $t_{\text {hitung }}>t_{\text {tabel }}(3,483>2,018)$. Motivasi Kerja secara parsial berpengaruh positif dan signifikan terhadap Kinerja Pegawai pada Dinas PMK,PP,PA Kota Sibolga. Dengan nilai $t_{\text {hitung }}>t_{\text {tabel }}(3,122>2,018)$ Kepemimpinan, Iklim organisasi dan Motivasi secara simultan berpengaruh terhadap Kinerja Pegawai pada Dinas PMK, PP \& PA Kota Sibolga.

\section{DAFTAR PUSTAKA}

Arikunto, S. 2001. Prosedur penelitian suatu pendekatan praktek. Jakarta: Rineka Cipta

Edy sutrisno. 2009. Manajemen Sumner Daya Mausia. Jakarta: Kencana Prenda Media Group

Hasibuan, SP. M. 2000. Manajemen Sumber Daya Manusia, Edisi Revisi. Jakarta: Bumi aksara.

Mangkunegara, Anwar Prabu. 2001. Manajemen Sumber Daya Manusia Perusahaan. Bandung: Remaja Rosdakarya

Robbins, S.P. \& Judge, T. A. 2015. Perilaku Organisasi. Edisi 16. Jakarta: Salemba Empat. 
